\title{
Perspectives
}

\section{"A Time to Break Down, and a Time to Build Up": Teacher Education in Ontario ${ }^{1}$}

David Mendelsohn

Before I even begin, I would like to say how honored I am to have been asked to give the Ian Gertsbain Memorial Lecture. Ian was a friend and colleague of mine. I am particularly happy to see Ian's mother, sister, brother-in-law, and his closest friends here once again. This annual Memorial Plenary is a wonderful opportunity for us all to remember Ian and to tell those of you who were not fortunate enough to have known him how much Ian meant to all of us in ESL. My topic, teacher education, was one dear to lan's heart, and I know that what I am going to say would have been in keeping with Ian's own ideas. So it is most fitting that I dedicate this to my late friend Ian Gertsbain.

\section{Introduction}

I wish to clarify something important from the outset: throughout this paper I make some serious criticisms of the Ontario Additional Qualification (AQ) courses for ESL. Let me be explicit: my criticism is of the courses, not of the people who take them nor of the people who teach on them, myself being one. What I am saying is, in fact, to the credit of these people, because I believe that we have come as far as we have in the profession not because of the courses, but because of the wonderful people in our profession.

The remarks I make refer primarily to Ontario, but I would think, from my limited knowledge of the situations in other provinces, that this may well be "a time to build up" for them too.

I recently gave a talk at a conference in Israel on a totally different topic, and called the talk "Disturbing Realities and Attainable Dreams." I could, in fact, quite comfortably plagiarize my own title and call this article "ESL Teacher Education: Disturbing Realities and Attainable Dreams," because I feel that in many ways this would precisely capture the situation with ESL teacher education in Ontario today.

It is my belief that the situation regarding TESL teacher education in Ontario is serious. And under the influence of recent government budget cuts, things are going from bad to worse.

In this article I briefly outline where we were a few months ago, and where we have regressed to since then. I then discuss the concept of profes- 
sionalism, suggesting that the teaching of ESL, a profession that has long been battling to be recognized as a fully fledged academic profession, is rapidly becoming deprofessionalized, partly due to government forces, and partly due to our own fault. I then suggest some basic principles and components that I believe a teacher education program should contain. Finally, surprisingly, I end on an optimistic note, as I contend that the undesirable situation that we find ourselves in due to the government's change of policy may yet turn out to be a blessing in disguise - that if we seize the moment, we may yet be able to fill the vacuum that is fast being created with something of value that we ourselves can be instrumental in creating and putting in place.

\section{ESL Teacher Education in Ontario: The Disturbing Reality}

There was a time when a person who was a native speaker of English could get a job in Ontario teaching ESL with no training whatsoever. Then came the period up to the mid 1970s when the government offered courses in TESL. In the mid 1970s, this responsibility was subcontracted to the faculties of education of the Ontario universities, and for six to eight years it was possible to do a BEd in TESL. Sadly, the legislation was changed around 1984, so that it was no longer possible to take TESL in a BEd course. The only TESL education for potential ESL teachers in the Ontario school system was offered in Additional Qualification (AQ) courses. This meant that people who had set their hearts on becoming ESL teachers in the school system had to do a BEd in some other discipline, say, for example, high school teaching of physical education and geography, yielding an Ontario Teachers' Certificate, and only then could they take Part I of the three-part ESL AQ courses in order to be recognized as a qualified ESL teacher. Without a BEd (which cannot be in TESL) followed by an ESL AQ course, the doors to permanent ESL positions in the Ontario schools are closed.

And what are, or maybe I should already be saying, what were the ESL $A Q$ courses like? I would argue that they are hopelessly inadequate, that an individual who has been trained in some other teaching discipline does not receive an adequate TESL education either theoretical or practical in Part I or, indeed, in all three of these courses, to be called an ESL professional, and certainly not, as the Ministry calls them after Part III, "specialists." The courses are too short, the guidelines under which they operate are out of date and in any case are all too often ignored, they provide little theoretical background for the teacher, and there is no practicum. In other words, it is possible to become a certified ESL teacher in Ontario on the basis of Part I of the three-part $A Q$ program without ever having taught an ESL class.

Let me repeat: it is the courses I am criticizing, not the participants or the teachers. I think that most of our teachers are excellent, committed, dedicated, and hard working. I feel that you have got where you are in spite of the 
$A Q$ courses, not because of them. And I believe that those of us who teach these $\mathrm{AQ}$ courses have been battling difficult circumstances.

Finally, I must add the ultimate irony of our disturbing reality: there exist a number of TESL courses in this province, not offered through faculties of education, such as the George Brown and Humber College TESL courses, the University of Toronto TESL Certificate at Woodsworth College, and others at Carleton University, Brock University, and elsewhere, which offer more substantial and demanding TESL courses than any AQ course that I have seen or read about. However, because we are straitjacketed by provincial legislation that states that this qualification can only be acquired through a faculty of education, graduates of these courses are not licensed to teach ESL in Ontario schools. True, some of those that I mentioned specialize in teaching ESL to adults, and they would have to be modified before being recognized, but several do not have this narrow focus, and in any case it is the principle that I am criticizing.

Let me highlight the three major anomalies that grow out of what I have said so far:

1. In order to be an ESL teacher you have to train in some other teaching discipline and then take an $A Q$ course.

2. Courses are erroneously and misleadingly labelled by the Ministry as "In-Service" courses; in ESL, the Part I course is not inservice at all, it is preservice, but by calling it inservice there has been no need to offer real inservice courses, because something called "in-service" exists.

3. For a teacher trained in another discipline to become a qualified ESL teacher, he or she needs to do no more than the Part I course, a short, hopelessly inadequate education for an ESL professional.

This is the situation as it exists today. Or is it? Until the spring of 1993, the Ministry of Education funded these AQ courses, so that the deliverers of the courses, the universities, were able to offer them at a reasonable cost to teachers. This spring saw a cut of $10 \%$ to the funding by the Ministry, with an announcement that the funding would be phased out totally over four years. The rationale, as explained to me by an official of the Ministry, is that they do not feel that they should have to fund courses that lead to an increment in salary. I totally reject this line of argument, and it certainly has no validity given that these are not in fact inservice courses. As I have stated, in the case of ESL they are preservice, and it is my opinion that the Ministry has failed to think through the implications of these cuts to disciplines like ESL. They would have done well to heed an old Bantu proverb that states: "Before you throw away what you have, make sure that you have something of value with which to replace it."

As many of you know, with the $10 \%$ cut in the summer of 1993, fees went up, and there was a significant drop in registration. In fact, York University, the largest deliverer of $\mathrm{AQ}$ courses in Ontario, traditionally covering $40 \%$ of 
all $A Q$ courses in the province, suspended its fall/winter $A Q$ courses because they can no longer be mounted without sustaining a large loss. I am told that Lakehead University did the same. It is my firm belief, and conversations with numerous senior people in faculties of education would confirm this, that we are seeing the beginning of the end of the AQ model of teacher education.

So that is our reality: an inadequate program in TESL, itself coming apart due to the withdrawal of funding.

And let me add another worry: despite the importance of ESL in this province, no one person or department in the Ministry of Education is responsible for ESL. As a result, ESL often falls through the cracks or is foisted onto some officials whose main interest and responsibility is not ESL.

\section{Professionalism and the Teaching of English as a Second Language}

Great efforts have been made by many people for many years to professionalize our ESL teaching profession, and, thanks to these people and to those who run such organizations as TESL Ontario and TESL Canada, significant progress has been made. More institutions are demanding that their teachers of ESL are suitably prepared, there is some lobbying, and there is a forum for exchanging ideas through fine conferences and mini-conferences, and through publications such as Contact and the TESL Canada Journal.

However, if we measure our profession against published definitions of the term profession, such as Mayhew's (1971), we quickly realize that we still have a long way to go, and some of the government-driven changes that I describe seem to be pushing us in the opposite direction. Mayhew defines a profession as follows:

A profession consists of individuals with specialized knowledge obtained through intensive education which allows them to provide esoteric services in a near-monopoly fashion to a public which recognizes and accepts the utility of the monopoly. (pp. 1-2)

ESL in Ontario fails to meet most of these criteria for being called a real "profession": the teachers' knowledge is usually less than specialized, ESL teachers' services are not viewed as "esoteric," because many still believe that anyone who speaks English can teach ESL, and the public certainly does not recognize the near monopoly of ESL teachers to teach ESL.

Mayhew goes on to add that a profession must also be altruistic: that its members must serve society and feel a deep and lifelong commitment to the practices and life-modes of the profession. These last two points are true of most dedicated ESL teachers: they are altruistic and deeply committed to the profession, despite the lack of recognition of TESL as a profession. 
Schein (1972) adds that one of the things that separates the professional from the amateur is that "the professional ... is engaged in a full-time occupation that comprises his principal source of income" (p. 8). Sadly, ESL teaching is not a full-time occupation for many ESL teachers. Again, we must look to the top, to the system, to explain why most ESL positions do not meet this criterion.

One of the consequences of greater professionalism would be that educational administrators would listen to us more, and respect us more, and what we do would acquire "academic respectability." With this would come greater power to influence our bosses on matters of program changes, program cuts, and so forth.

But it is too easy for us to sit back and nod in pained but passive agreement with what I am saying. If we are to achieve this professionalization in the face of adversity, we must alter the mindset that we have been conditioned to accept, of ESL being a service rather than a discipline. What is more, we must heed the advice given by Ashworth (1985) in her excellent book Beyond Methodology and begin to be proactive, both in our places of work and in the time, attention, and active support that we give to our professional organizations such as TESL Ontario. We must empower our professional organizations. Through them we must ensure that only people adequately educated be allowed to teach. The Ministry of Education would argue that the requirement to have ESL Part I does precisely that. I would disagree, arguing that they certify teachers who are not adequately prepared, and, what is more, they exclude teachers from the non-AQ TESL programs who are satisfactorily prepared. Toward the end of this article I suggest that this problem can only be solved when the Ministry-sanctioned TESL courses are modified, and, what is more, given the ESL void I sense in the Ministry, when the licensing of ESL teachers is handed over to a group of ESL professionals, preferably under the auspices of TESL Ontario.

The Bantu proverb said that before throwing away what you have, make sure you have something of value with which to replace it. I now try to offer some thoughts and suggestions as to what this "something of value" should look like or contain if we are given the opportunity to replace the existing TESL AQ framework and content. I speak primarily about preservice courses, and then briefly about inservice.

\section{Good TESL Teacher Education}

A general problem with all teacher education stems from the fact that teaching is not an easy thing to do. As Clark (1988) says, "teaching is complex, uncertain and dilemma-riddled" (p. 10). He goes on to suggest that as a result of this uncertainty and complexity, teaching is "less a matter of knowing all the answers than a matter of making the most of the unexpected." This does 
not mean that there is no body of knowledge to be learned, but that prospective teachers should not expect to get all their questions answered.

\section{Teacher Education is Our Goal, Not Teacher Training}

Which are we aiming at, teacher education or teacher training, and what is the difference? Richards (1993) offered the most graphic and succinct answer to this question at a conference I recently attended by drawing an analogy with sex: surely, he argues, at school, we aim at sex education, not at sex training!

In a more detailed answer to this question, Widdowson (1984) speaks of "training" as providing techniques in order to achieve certain clearly specified objectives. In training, the goal is predetermined, and the most effective way of achieving it is never in question. This, clearly, is too narrow and simplistic a target for TESL teacher preparation.

\section{The Goal of Teacher Education}

I would like to endorse Larsen-Freeman's (1983) definition of the goal of teacher education: to make the trainee teacher an effective teacher able to adapt to and function in any situation. To achieve this goal, she argues, students must become "independent learners ... [who can] set objectives, define problems, generate hypotheses, gather information, make decisions and assess outcomes" (p. 265). In addition, as teachers acquire more experience they must be the initiators of change.

I maintain that the curriculum must include a theoretical base of knowledge, a framework for discussing and planning how to teach, and also a practicum. I expand on these below.

\section{The Underlying Principles of a Teacher Education Program}

I am calling for an approach in which the focus is on studying and analyzing the processes of second language learning and teaching rather than on the results. And this certainly cannot be achieved in a BEd in some other discipline. The present reality tacitly denies the need (discussed below) for a second language teacher to be educated in such areas as linguistics, second language acquisition, sociolinguistics, and so forth.

The approach I advocate does not claim to provide all the answers, but it certainly helps students to think reflectively about their learning and teaching. What is more, it leads to a situation in which the teacher educator ceases to be placed on a pedestal, supposedly with all the answers. Rather, the teacher becomes a person with whom students can share their fears, discuss their reflections, and ask their questions without danger of ridicule.

So when I talk of teacher education, I see it as a process of lifelong learning that should last as long as the teacher is teaching. It begins with a 
preservice teacher preparation course, but then continues in various shapes and formats as inservice, and is available to as many teachers as possible.

Freeman and Richards (1993), ${ }^{2}$ in an excellent paper, also see teacher education as an ongoing process and acknowledge that quite a bit of what is done in a preservice course will by definition tend to be prescriptive because a body of knowledge has to be covered. Then, at a later stage in their teacher development, they will be able to draw on their classroom experience and think philosophically and critically about what they have been doing and why. This process should begin during the preservice course, as a part of the practice teaching segment of the course, but, even more importantly, should continue as a major part of inservice.

\section{Preservice TESL Preparation Courses}

\section{Preservice Courses: Underlying Principles}

Several years ago, Thomas Keane, the then Governor of New Jersey, proposed a solution to the teacher education problem: select bright graduates who are well prepared in their field, place them in schools with highly competent and cooperative teachers for a year, after which certify them as qualified for a teaching career, especially given that he considered most existing teacher-preparation courses to be "Mickey Mouse," and therefore getting rid of them would not be a great loss. Let me be absolutely clear: This is not what I am advocating. Keane's plan would have been a classic case of "throwing out the baby with the bathwater:" As Wing (1993) argues, if we followed Keane's idea and focused only on what goes on in the classroom, we would tend to perpetuate the past rather than developing a vision of the future. I am advocating maintaining, but improving teacher education courses. And I believe there are three major components of a good TESL preparation course: the theory part, the methodology part, and the practicum or practice teaching part, all of which are indispensable, interlink, and should cross-fertilize each other.

The overall goal of a preservice program would be to educate the trainee teachers to a level of intellectual independence that would enable them to be competent teachers open to new ideas, possessing the confidence and ability to judge these ideas critically and not to be carried along by every passing bandwagon.

\section{Preservices Courses: The Theory Part}

When I began working on this paper, I was looking for a short, pithy way of making the case for theory in preservice TESL preparation courses, and my dreams came true in the Globe and Mail on September 6, 1993, when the following appeared as the "Quote of the Day" said by historian Diane Ravitch: "The person who knows 'how' will always have a job. The person who knows 'why' will always be his boss." I think that says it all. It is clearly 
not enough to know how as an ESL teacher: we must also know why. True professionals are never satisfied with knowing how because without also knowing why, this automatically places them in a weak and vulnerable situation.

Making the case for including theory. What a teacher needs is a sound education in the theory underlying ESL learning and teaching, and I discuss why and what this includes.

Despite the fact that there is a body of knowledge that teachers need, often prospective teachers in TESL courses complain that their courses are too theoretical. This is partly the fault of those of us who work in teacher education programs and the way in which we present the material. We cannot assume that the preservice, inexperienced, prospective teacher enters the program convinced of the value of theory. It is not, nor should it be the goal of those who teach the theory part of TESL courses to turn their students into applied linguists. It is up to us to teach the theory in such a way that students recognize the need for theory and its value. After all, it is through theory that teachers become aware and increase the options open to them. We must, therefore, cover aspects of the theory that have clear pedagogical implications, and the link between theory and practice must be pointed out and emphasized throughout. Freeman (1991) draws the analogy with literature: the literary critic is the theorist who must know how to recognize "good" poetry and the literature teacher is the classroom teacher who must know how to recognize "good" poetry, but must also know how to get the students to recognize and understand its "goodness." This requires making theory accessible, user-friendly, and applicable. Ur (1993) takes this one step further, calling on ESL teachers to take the following approach to theory: "Adapt, don't adopt."

Ultimately, as stated above, knowledge of theory leads to the intellectual independence that all of us in teacher education try to inculcate in our students.

Students studying to be teachers tend to want instant and watertight solutions to all their pedagogical questions and sometimes feel let down if they don't get them, and this leads to a distrust of theory. This kind of impression is, first and foremost, the result of teacher educators failing to make it clear to their students that they should not expect all the answers through their teacher education course, but should rather hope through it to be equipped to handle the ongoing questions and issues that will arise as they teach. A subsidiary reason for the practitioner-to-be's distrust of the theorist is that some theorists in our profession have not taught an ESL class for many years and have, indeed, become disconnected from the classroom reality, and this is often discernable in some of their claims.

Although I am at pains in this article to make the case for the inclusion of theory in all teacher education programs, it would be irresponsible of me not 
to acknowledge the limitations of theory. The theorist, in order to be sound in terms of research design and statistics, has to idealize reality in order to tease out and control for variables that can get in the way of the research. This by definition makes such research somewhat artificial and cannot, therefore, be accepted as is for classroom application. Instead of lauding the product of the study, the classroom practitioners should laud the process of inquiry and follow it up with associated classroom-based inquiry of their own.

To summarize this point: the theory part should provide the theoretical underpinnings for the practical work in a teacher education program, be it preservice or inservice, so that the theory is accountable to the practice, but, as I argue later, the practice must also be accountable to the theory (Widdowson, 1984). This means a blending of theory and practice rather than a compartmentalization of the two as is usually the reality in teacher education.

Not only must theory be linked to practice, but it is not uncommon that they overlap. An example would be pedagogical grammar, which, I believe, has to cover a body of grammatical knowledge that an ESL teacher needs, plus discussion as to how it should be taught.

What should be included in the theory part? This is not a simple question, as the theoretical basis of ESL teaching has increased enormously, and the body of relevant knowledge from related fields grows by the day.

What I attempt to do now is to list some of the essential areas that the theory part of the course should include. This does not claim to be an exhaustive list, but it will at least give an indication of what needs to be addressed:

1. second and first language acquisition;

2. linguistics;

3. the structure of English (all systems, including the discourse level);

4. learner language;

5. the psychological, sociological and linguistic implications of being an immigrant;

6. sociocultural awareness and antiracist education;

7. pedagogical grammar;

8. curriculum design;

9. language testing;

10. learner-centered teaching, for example, cooperative learning;

11. classroom management;

12. classroom-based research. 
The overlap with the methodology part is immediately apparent. This overlap is natural and realistic and strengthens my argument not to overcompartmentalize the different parts of the course.

\section{Preservice Courses: The Methodology Part}

The theoretical and methodological parts of a teacher education program overlap, and should by definition be closely aligned. What is more, whenever a method is being advocated, the theoretical basis should always be clarified, tying theory and practice together. Similarly, methodology should not be separated from the practice teaching part of the course, because, as I point out below, there is only limited value to a methodology course unless it also overlaps with the practicum.

Let me start with four points concerning methodology that I believe are important. First, I do not believe that generic pedagogy courses are sufficient. Neither do I believe that by receiving teacher education in a discipline other than ESL one is ready to teach ESL. I mention this rather obvious point because of the situation with existing $A Q$ courses in which there is a tacit assumption by the Ministry of Education that people entering ESL AQ Part I courses are close to being ready to teach ESL because of already being certified teachers of something else.

Second, given that so much is open to debate about so many aspects of ESL teaching, we must be careful not to give the impression in the methods course that there are hard and fast answers. This impression is, unfortunately, easily conveyed, for example, by the ways in which we assess and assign grades in such courses: "You get it 'right,' you get a high grade." This should, I believe, be replaced by an "analysis and discussion" model focusing on the process. $^{3}$

My third point is that we must be sure to include special needs or the teaching of special groups in our methods course. Most TESL programs that I am familiar with tend to neglect or to treat inadequately the issue of the teaching of ESL to young children at elementary school. Another example would be teaching nonliterate students.

Fourth, we must be careful not to teach prospective teachers to do things that do not work or are not viable. Clark (1988) cites an excellent example of this, in which, in a certain program, students were told that they should not use existing textbooks but should design their own materials. Not only did the course not adequately teach them how to do this, but most of the teachers who were supervising their practicum were using existing textbooks.

All of the above brings us to the question of what, in fact, should be covered in a methods course. Again, let me say this is not intended to be a curriculum, but it merely aims at spelling out some of the main areas:

1. simulations of real classroom situations to facilitate discussion of such things as discipline; 
2. units of work on different aspects of language teaching, for example, how to teach stress and intonation, how to correct errors in the writing and speaking of the students, how to teach vocabulary, pronunciation, listening, etc.;

3. case studies based on videos of lessons of experienced teachers;

4. peer teaching of different topics;

5. self and group analysis of the teaching, micro-teaching, or peer teaching of the trainee teachers themselves;

6. evaluation of published materials;

7. learning to design or evaluate a lesson, a curriculum, a classroom test and an examination;

8. the evaluation and comparison of different teaching methods;

9. discussion of classroom management, for example, how to organize group work, and how to design, give out, correct, and return homework (see Richards, 1993, 1987; Wing, 1993, Johnson, 1992; Freeman, 1991; Yalden, 1983 for further detail).

Preservices Courses: The Practice-Teaching or Practicum Part

If earlier I spoke of the overlap and essential links between methodology and the practicum, here I would like to revisit the theory part of the course. The practicum is the place where the prospective teacher can try out the theories so as not to have to rely on what the gurus say works, nor to rely on the theories in an untried way.

Until now I have taken care to emphasize the importance of theory, but this in no way diminishes the importance of practice. Richards and Hino in their 1983 study found that teachers learn by doing much more than by taking methods courses. Moreover, it is only by doing, that is, by teaching, that a student studying to be a teacher grasps the limitations that particular teaching circumstances can create, however good an idea may have seemed in the methods course. By doing, they also grasp fundamental pedagogical facts such as the fact that a wonderful activity will probably turn out to be an unmitigated disaster if the teacher does not know how to give the instructions clearly.

So it is imperative that a teacher education program have a practicum, and the practicum should be extensive, and the practicum must also be good. It must be carefully planned and supervised, not just an opportunity for unstructured lesson observation and/or teaching.

What, then, is the value of the practicum?

1. It heightens awareness, leading either to an affirmation of what is being done or to a desire to try make changes.

2. It encourages the teacher, with suitable supervision and handholding, to be the initiator of change in approach or method. Ur (1993) maintains 
that in her teacher education courses she makes her students promise to do something risky.

3. It leads to change in the way things are done by the prospective teacher; for example, it can lead to a reduction in the amount of teacher talk, if this is found to be necessary.

4. It leads to the development of an awareness of self in the classroom, largely through discussion and reflection and by the teacher educator sharing his or her experiences, including failures and unresolved pedagogical agonies.

5. It triggers the desire in the prospective teacher to continue to reflect, evaluate and explore (Freeman, 1989).

The practicum should include keeping journals, including "lesson reports"; the prospective teachers should serve as ESL teachers' aides or apprentices for lengthy periods; they should do one-on-one tutoring and microteaching in their supervisor's class; they should do extensive, planned and supervised observation and actual teaching; and, finally, they should do a lot of self-observation through analyzing themselves on video. All of this heightening of awareness, questioning, and practice will lead to an ongoing self-evaluation that, in turn, will yield classroom-based research in the framework of inservice.

I would like to conclude this section with a practical but important point: the practicum will only be good if the teachers who are working with the prospective teachers are suitably rewarded for their efforts. This is too important a matter to leave up to the goodwill and altruism of the profession. It is really a case of calling on the authorities to "put their money where their mouth is," and this point should never be lost in planning teacher education programs.

\section{Inservice TESL Teacher Education}

If we as teachers do not participate in ongoing teacher education programs, we stagnate - our teaching never changes, we fail to be self-critical, and we do not renew ourselves and find out what new and exciting ideas, methods, and technologies are emerging.

I believe that teaching is developmental and not something that we can just learn in a preservice course. It requires lifelong learning. Teachers change and grow over time, and this has been borne out by extensive research (Freeman, 1990; Oja, 1990; Oja \& Smulyan, 1989; Berliner, 1986, 1988). And as practicing teachers gain experience, this is the time for them to think critically and philosophically about what they are doing and why-what Richards (1993) calls "reflective teaching." Consequently, inservice is not merely desirable, but essential. Through good inservice programs, teachers develop the confidence to grapple with problems they are having in their 
teaching and to try to make changes, even though they do not have, and will never have, all the answers. Or, to quote Peter Norman of Simon Fraser University, the motto for inservice should be: "Get curious, not cured."

Inservice programs should not just be a continuation of preservice courses. I believe that inservice courses should be investigative and based on classroom research, with most of the issues to be covered determined by the teachers themselves. Not only should the program be developed collaboratively, but frameworks should be created to ensure collaboration between teachers teaching different age groups, at different levels, and in different circumstances.

In British Columbia, they have developed what they call their Comet Model for inservice education (not initially for ESL at all), and I think it is promising and exciting. It is based on the precepts I mention above. First, teachers attend noncredit summer institutes on a particular topic. They then do intensive investigation of the issues, together with further reading and action research, and this together constitutes a credit, inservice course. It really boils down to the teachers taking the information from their summer institutes and trying to implement it.

Teachers' reactions to the Comet Model have been positive. They have a sense of ownership of the projects. There is great enthusiasm, as they are applying ideas to their own situations, and getting support while doing this, plus, they are receiving credit for it. It sounds like a "win-win" formula. ${ }^{4}$

\section{What Does all this Mean for Teacher Education in Ontario?}

I promise at the beginning of this article to end on an optimistic note, so here it is: I believe that we must view the present Ontario situation as a window of opportunity. I believe that we are moving toward a vacuum in TESL teacher education, and it is up to us to become proactive in advocating frameworks, programs, and models that will be to our liking and will enhance the professionalism of ESL. We cannot wait for the word to come from above-we must act. So who is "we"? First and foremost, "we" is the TESL Association of Ontario. We have a vibrant professional organization, and it should become the mouthpiece of TESL, even to a greater extent than it has been in the past. At this moment a Royal Commission is at work on matters related to teacher education that will clearly affect our profession. Who is advising them vis-à-vis ESL, and what are they planning?

I do not think that it is beyond the bounds of possibility that TESL Ontario could become the licensing body for Ontario ESL teachers. After all, many other professions are self-governing, and the Province empowers them to license and de-license-legislation is being completed to empower the future Ontario College of Midwives to do just that, so why not our profession? And if we should succeed, then I would advocate a two-step licensing procedure, a bit like the proposed "graduated drivers' license," whereby the teachers 
would complete their preservice course with the status of novice teacher. They would then have to work for, say, two years in ESL and meet certain other requirements of the reflective, self-evaluatory nature before being awarded a permanent Ontario Teacher's Certificate. I have no illusions as to the complexity of what I am advocating, including the need to amend existing legislation, but it can be done.

I would love to see a totally revamped preservice TESL teacher education program, substantial in length and substantive in content, of the type I discuss, and including an extensive and carefully planned practicum. The quality of the program should be the determining factor as to whether the course leads to teacher certification, not simply whether the deliverer is a faculty of education, as present legislation dictates. This would finally lead to appropriate recognition for the excellent non-faculty of education TESL teacher education programs that exist. In addition, I call on the Ministry of Education to create a framework for real inservice work, perhaps along the lines of the BC Comet Model. Our present conferences, mini-conferences, and professional development days are not sufficient. We need to rework all the programs with maximum collaboration at all levels.

If we become proactive, I am confident that government will listen. I believe that given the decentralized responsibility for ESL in the Ministry, they would be only too happy to see a stronger professional organization willing to take on these responsibilities.

However, a word of caution: even if you agree with everything I have said, nothing will be done and the government will go its own way unless we have a plan to offer to them. Remember the Bantu proverb: "Before you throw away what you have, make sure that you have something of value with which to replace it." I say to all of you, and first and foremost, I address this to the newly elected Executive of TESL Ontario: Carpe diem!

\section{Acknowledgments}

I would like to thank Nick Elson and Peter Avery for their feedback on this paper, and Razika Sanaoui and Stan Shapson for their input.

Notes

${ }^{1}$ This paper was originally delivered as the Ian Gertsbain Memorial Plenary Address at the Annual TESL Ontario Conference in Toronto on November 27, 1993. Title taken from Ecclesiastes, 3:3.

${ }^{2}$ Based on Zahoric's (1986) conceptualization of teaching.

${ }^{3}$ Some interesting examples of how this can be done may be found at Carleton University in the TESL Certificate program.

${ }^{4}$ Based on a talk on 4.10 .93 at York University, given by Peter Norman, Director of Project Development, Simon Fraser University.

References

Ashworth, M. (1985). Beyond methodology. Cambridge: Cambridge University Press. 
Berliner, D. (1986). In search of the expert pedagogue. Educational Researcher, 15(7), 5-13.

Berliner, D. (1988). The development of expertise in pedagogy. Washington, DC: American Association of Colleges for Teacher Education.

Clark, C.M. (1988). Asking the right questions about teacher preparation: Contributions of research on teacher thinking. Educational Researcher, 17(2), 5-12.

Freeman, D. (1989). Teacher training, development and decision making: A model of teaching and related strategies for language teacher education. TESOL Quarterly, 23, 27-46.

Freeman, D. (1990). Thoughtful work. Reconceptualizing the research literature on teacher thinking. Unpublished manuscript, Harvard Graduate School of Education.

Freeman, D. (1991). Mistaken constructs: Reexamining the nature and assumptions of language teacher education. In J. Alatis (Ed.), Georgetown University round table on languages and linguistics. Linguistics and language pedagogy: the state of the art (pp. 25-39). Washington, DC: Georgetown University Press.

Freeman, D., \& Richards, J.C. (1993). Conceptions of teaching and the education of second language teachers. TESOL Quarterly, 27, 193-216.

Johnson, K.E. (1992). Learning and teaching: Instructional actions and decisions of preservice ESL teachers. TESOL Quarterly, 26,507-536.

Larsen-Freeman, D. (1983). Training teachers or educating a teacher. In J. Alatis, H.H. Stern, \& P. Strevens (Eds.), Georgetown University round table on languages and linguistics. Applied linguistics and the preparation of second language teachers: Towards a rationale (pp. 264-274). Washington, DC: Georgetown University Press.

Mayhew, L. (1971). Changing practices in education for the professions. Atlanta, GA: Regional Education Board.

Oja, S. (1990). Developmental theories and the professional development of teachers. Paper presented at the American Educational Research Association Annual Meeting, Boston.

Oja, S., \& Smulyan, L. (1989). Collaborative action research: A developmental process. London: Falmer Press.

Richards, J.C. (1987). The dilemma of teacher education in TESOL. TESOL Quarterly, 21, 209-226.

Richards, J.C. (1993). Reflective teaching: A consumer's guide. Paper presented at the English Teachers' Association of Israel Conference, Jerusalem.

Richards, J.C., \& Hino, N. (1983). Training ESOL teachers: The need for needs assessment. In J. Alatis, H.H. Stern, \& P. Strevens (Eds.), Georgetown University round table on languages and linguistics. Applied linguistics and the preparation of second language teachers: Towards a rationale (pp. 312-327). Washington, DC: Georgetown University Press.

Schein, E.H. (1972). Professional education: Some new directions. New York: McGraw Hill.

Ur, P. (1993). Realities and dreams. Paper presented at the English Teachers' Association of Israel Conference, Jerusalem.

Widdowson, H.G. (1984). The role of theory in practice. In H.G. Widdowson (Ed.), Explorations in applied linguistics (vol. 2, pp. 28-36). Oxford: Oxford University Press.

Wing, B. (1993). The pedagogical imperative in foreign language teacher education. In G. Gunterman (Ed.), Developing language teachers for a changing world (pp. 159-186). Lincolnwood: National Textbook Company.

Yalden, J. (1983). Training needs in the 80s: The ESL teacher in Canada. Canadian Modern Language Review, 40, 19-22.

Zahorik, J. (1986). Acquiring teaching skills. Journal of Teacher Education, 27(2), 21-25. 